\section{Particulars of the}

JOURNALS

Published by the

Cambridge University Press,

and rates for advertisements

may be bad from

THE MANAGER

CAMBRIDGE UNIVERSITY PRESS

BENTLEY HOUSE

200 EUSTON ROAD

LONDON, N.W. 1
Animal Nutrition. Man with practical knowledge of this subject wanted by old-established Company in Nairobi, Kenya. Applicants must be graduates with a Science Degree and a Diploma in Agriculture. Single or married man acceptable. Main duties will be (a) designing formulae, (b) advising ernployers on development of Feeds business, and (c) giving sound advice to farmers on nutritional matters. Free air passages, accommodation, home leave, superannuation and medical benefitprivileges. Excellent prospects.

Write Box “FE/r43"

c/o 95 BISHOPSGATE, B.C. 2

The fournal of Agricultural Science is issued in quarterly parts of about 120 pages with plates and figures, four parts constituting a volume.

Volumes XVI-XX (1926-1930) are out of print. Quotations can be given for other back volumes and parts.

Quotations can also be given for buckram binding cases. (Suspended.)

Papers for publication should be typewritten or written in a very legible hand, and may be sent to DR J. HAMmOND, School of Agriculture, Cambridge, or to the associate Editors. Other communications should be addressed to the University Press, Cambridge.

If Plates in excess of one per 24 pages of text are submitted the aurhor may be asked to bear the cost of such Plates.

Bibliography should be given under the heading of "References" in the following form:

Surname of authors (in alphabetical order), initials, date of publication (in brackets), title of Journal (abbreviated according to the World List of Scientific Periodicals), volume and pages of reference. In the text a reference should be quoted by the author's name and date (in brackets).

All names of Journals and books should be in italics.

Contributors will receive twenty-five copies of their papers free.

The subscription price, payable in advance, is 605 . net per volume (post free); single numbers 20s. net. Subscriptions may be sent to any bookseller, or to The Cambridge University Press, Bentley House, 200 Euston Road, London, N.W. I.

Subscription price in the U.S.A. is \$10.50 per volume; single numbers \$3.50. Enquiries should be addressed to the Cambridge University Press American Branch, 32 East 57th Street, New York, 22. 


\section{CONTENTS}

Lutwak-ManN, C. and Rowson, L. E. A. The chemical composition of the pre-sperm fraction of bull ejaculate obtained by electrical stimulation $. \quad . \quad . \quad . \quad . \quad . \quad . \quad . \quad . \quad . \quad$.

Hughes, G. Pearson and Eyles, Dudley E. Extracted herbage leaf protein for poultry feeding. I. Introduction and feeding trial with laying hens

Hughes, G. Pearson and Eyles, Dudley E. Extracted herbage leaf protein for poultry feeding. II. The use of leaf protein in chick rations. (With Two Text-figures)

Hughes, G. Pearson and Eyles, Dudley E. Extracted herbage leaf protein for poultry feeding. III. The digestibility of the residual product resulting from the extraction of herbage leaf protein .

GLover, J. The nutrition of maize in sand culture. I. The balance of nutrition with particular reference to the level of supply of nitrogen and phosphorus. (With Two Text-figures) . . . .

GLOVER, J. The nutrition of maize in sand culture. II. The uptake of nitrogen and phosphorus and its relevance to plant analysis. (With Three Text-figures)

Dodsworth, T. L. and CAmpbell, W. H. McK. Report on a further experiment to compare the fattening values, for beef cattle, of silage made from grass cut at different stages of growth, together with the results of some supplementary experiments. (With Thirteen Textfigures)

DONALD, H. P. and HANCOCK, J. L. Evidence of gene-controlled sterility in bulls

Pomeroy, R. W. Studies on piglet mortality. I. Effect of low temperature and low plane of nutrition on the rectal temperature of the young pig. (With Nine Text-figures)

LuCAS, I. A. M. and Tномson, W. The effect of flooring upon pigs reared in an otherwise cold environment. (With Two Text-figures)

YeAtES, N. T. M. The effect of high air temperature on reproduction in the ewe.

SACHS, LEO. The occurrence of hybrid semi-lethals and the cytology of Triticum macha and Triticum vavilovi. (With Plates 5 and 6) . .

HeAD, M. J. The effect of pregnancy and lactation in the ewe on the digestibility of the ration with a note on the partition of nitrogen in the foetus at full term

YOUNG, GILBERT B. A study of genotype environment interaction in

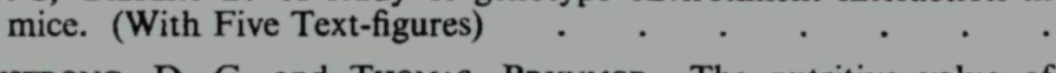

Armstrong, D. G. and Thomas, Brynmor. The nutritive value of Calluna vulgaris. II. A preliminary study of digestibility

BIRCH, H. F. Phosphate response, base saturation and silica relationships in acid soils

LEECH, F. B. and BAILEY, G. L. The effect on the health of lactating cows of treatment with galactopoietic doses of thyroxine or iodinated casein 